\title{
Pichia pastoris Aft1 - a novel transcription factor, enhancing recombinant protein secretion
}

\author{
Claudia Ruth ${ }^{1 \dagger}$, Markus Buchetics ${ }^{2 \dagger}$, Viktorija Vidimce ${ }^{1}$, Daniela Kotz ${ }^{3}$, Stefan Naschberger ${ }^{3}$, Diethard Mattanovich ${ }^{2,4}$, \\ Harald Pichler ${ }^{1,5^{*}}$ and Brigitte Gasser $2,4^{*}$
}

\begin{abstract}
Background: The methylotrophic yeast Pichia pastoris is frequently used for the production of recombinant proteins. However, expression levels can vary depending on the target protein. Allowing for simultaneous regulation of many genes, which may elicit a desired phenotype like increased protein production, overexpression of transcription factors can be used to overcome expression bottlenecks. Here, we present a novel P. pastoris transcription factor currently annotated as Aft1, activator of ferrous transport.

Results: The promoter regions of key secretory P. pastoris genes were screened for fungal transcription factor binding sites, revealing Aft1 as an interesting candidate for improving secretion. Genome wide analysis of transcription factor binding sites suggested Aft1 to be involved in the regulation of many secretory genes, but also indicated possible novel functions in carbohydrate metabolism. No Aft binding sites were found in promoters of characteristic iron homeostasis genes in P. pastoris. Microarrays were used to study the Aft1 regulon in detail, confirming Aft1 involvement in the regulation of carbon-responsive genes, and showing that iron regulation is dependent on FEP1, but not AFT1 expression levels. The positive effect of AFT1 overexpression on recombinant protein secretion was demonstrated for a carboxylesterase from Sphingopyxis sp. MTA144, for which secretion was improved 2.5-fold in fed batch bioreactor cultivations.
\end{abstract}

Conclusion: This study demonstrates that the transcription factor Aft 1 can be used to improve recombinant protein secretion in P. pastoris. Furthermore, we discovered possible novel functions of Aft1 in carbohydrate metabolism and provide evidence arguing against a direct role of Aft1 in P. pastoris iron regulation.

Keywords: Pichia pastoris, Aft1, Transcription factor, Novel functions, Enhanced secretion

\section{Background}

The methylotrophic yeast Pichia pastoris (syn. Komagataella phaffii) is among today's most frequently used yeast systems for the production of recombinant proteins [1]. Benefits of this yeast are the capability of high cell density cultivations, eukaryotic posttranslational modifications and good secretion capacity. A low level of endogenously secreted proteins allows for the production of relatively pure, recombinant secretory proteins. The recent availability of the genomic sequence boosted the generation of

\footnotetext{
* Correspondence: harald.pichler@tugraz.at; brigitte.gasser@boku.ac.at ${ }^{\dagger}$ Equal contributors

${ }^{1}$ Austrian Centre of Industrial Biotechnology (AClB GmbH), Petersgasse 14, 8010 Graz, Austria

${ }^{2}$ Austrian Centre of Industrial Biotechnology (ACIB GmbH), Muthgasse 11, 1190 Wien, Austria

Full list of author information is available at the end of the article
}

a versatile $P$. pastoris toolbox, including various strains, plasmids and promoters of different strength. To overcome individual bottlenecks during protein folding and secretion, a variety of helper factors such as the ER foldases Pdi1 or BiP (Kar2) have been studied in recent years $[2,3]$. The capability of transcription factors (TFs) as expression helpers was demonstrated by Guerfal et al. and Gasser et al. [4,5], who improved the secretion of the mIL-10 protein and antibody fragments by overexpression of the UPR (unfolded protein response) transcription factor $H A C 1$. Also overexpression of the gene encoding the TF Nrg1 was shown to positively influence the secretion of recombinant porcine and human trypsinogen as well as the antibody Fab fragment 2 F5 [6].

Allowing for the simultaneous regulation of different proteins involved in e.g. folding and secretion, TFs have 
huge potential to overcome bottlenecks in the cellular protein production machinery.

Here, we present a novel $P$. pastoris TF which was annotated as Aft1 (Activator of ferrous transport) by sequence homology to Saccharomyces cerevisiae Aft1/2. While no information is currently available on the function of P. pastoris Aft1, its two S. cerevisiae homologs have been studied extensively. In S. cerevisiae the transcriptional activators Aft $1 / 2$ are responsible for iron uptake and homeostasis fulfilling overlapping but nonredundant roles $[7,8]$. It was shown that iron homeostasis is primarily maintained by Aft1, while Aft2 is the weaker transcriptional activator $[8,9]$. Still, both TFs can interact with the same iron-responsive element (FeRE) found within promoters of the genes of the iron regulon such as the iron reductases FRE1-6 or the multicopper oxidases FET3/FET5 [8]. Under iron limiting conditions, Aft1 binds to promoters of the iron regulon genes and increases their expression [10,11]. Under iron repletion, the monothiol glutaredoxins (Grx3/4) attached to an iron-sulfur cluster bind Aft1 and initiate its dissociation from target promoters [12]. Export of Aft1 from the nucleus is mediated by the nuclear export receptor Msn5 [13]. Several amino acid (aa) residues have been shown to be important for the iron-responsive regulation of Aft1. While phosphorylation of Ser210/Ser224 and an intermolecular interaction are essential for recognition by Msn5 [13], the residues Leu99, Leu102, Cys291, Cys293 are involved in the interaction with Grx3/4 and iron dependent regulation [12].

In contrast to $S$. cerevisiae, in most fungi such as Candida albicans, Pichia stipitis or Schizosaccharomyces pombe, the iron-regulatory pathway is controlled by a conserved zinc finger GATA-type repressor [14,15]. Also in $P$. pastoris iron uptake was shown to be under control of a GATA-factor, named Fep1. Fep1 was shown to bind to DNA only under iron repletion and disruption of FEP1 led to constitutively high expression of FET3, independent of the availability of iron [16]. Interestingly, several species such as C. albicans, P. stipitis and also $P$. pastoris have been found to possess an Aft-type regulator in addition to the GATA-type repressor, leading to the question on the function of Aft in these species $[16,17]$.

In this study, we investigated the functions of the P. pastoris Aft1 regulator based on the prediction of putative Aft binding sites in promoters, focusing on the secretion of recombinant proteins. We provide evidence that Aft1 is not directly involved in P. pastoris iron regulation, but rather in carbon-responsive regulation. Furthermore, we show that $A F T 1$, when overexpressed under its natural promoter, increased the secretion of a model protein up to 2.5 -fold in fed batch bioreactor cultivations.

\section{Results and discussion}

Analysis of transcription factor binding sites in selected genes shown to enhance protein secretion

To identify novel TFs useful for improving protein secretion in P. pastoris, the promoter regions, i.e. 1000 bp upstream of the ATG start codon, of key secretory genes involved in folding, transport and exocytosis were studied for putative fungal TF binding sites using the program MatInspector (Genomatix, [18]). The following genes, which were previously identified to improve secretion if modified $[4,5,19,20]$, and/or differentially regulated upon expression of a human sialic acid transporter [21], were studied: ERO1, HAC1, KAR2, PDI1, YDJ1, CNE1, SSE1, SSA4, SSB1, IRE1, UBI4, KIN2, SSO2, CUP5, CDS1, PGS1, ERG1, ERG3, ERG25, NCP1 and INO1.

Obtained TF hits were analysed according to frequency, function (link to the secretory machinery or stress response), matrix similarity (similarity of the input sequence to TF matrixes stored in the database, cut-off 0.9 ) and distance to the start codon (proximal more weighty than distal).

S. cerevisiae Aft1/2 binding sites were found enriched in the P. pastoris genes PDI1, KAR2, SSA4, KIN2 and NCP1 (Table 1). By sequence homology, the gene product of PAS_chr1-4_0361/PP7435_Chr1-1146 [NCBI] was identified as the single $P$. pastoris Aft protein, therefore called Aft1.

Table 1 Putative $P$. pastoris Aft 1 binding sites found in promoters of selected genes known to enhance protein secretion

\begin{tabular}{llll}
\hline Gene & Functions $^{\text {a }}$ & $\begin{array}{l}\text { Aft1 UBS } \\
\text { (bp) }\end{array}$ & Sequence \\
\hline PDI1 & $\begin{array}{l}\text { Protein disulfide isomerase, } \\
\text { ER chaperone, formation of } \\
\text { disulfide bonds }\end{array}$ & $-423^{\mathrm{b}}$ to -409 gatcacaCACCctct \\
KAR2 & $\begin{array}{l}\text { ER chaperone, mediating } \\
\text { protein folding, UPR } \\
\text { regulation }\end{array}$ & $-870^{\mathrm{b}}$ to -856 tcgtataCACCctca \\
SSA4 & $\begin{array}{l}\text { HSP70 protein, co-translational } \\
\text { protein-membrane targeting } \\
\text { and translocation of nascent } \\
\text { proteins into the ER }\end{array}$ & $-608^{\mathrm{c}}$ to -594 actcatgCACCctta \\
KIN2 & $\begin{array}{l}\text { Serine/threonine kinase } \\
\text { involved in exocytosis }\end{array}$ & $-177^{\mathrm{c}}$ to -163 ataactgCACCcaga & catggaaCACCccat \\
NCP1 & $\begin{array}{l}\text { P450 reductase, involved in } \\
\text { lipid metabolism (ergosterol } \\
\text { biosynthesis) }\end{array}$ & $-539^{\mathrm{c}}$ to -525 ggtttgCACCcagg \\
\hline
\end{tabular}

${ }^{\text {a }}$ functions are derived for the $S$. cerevisiae homologs of the $P$. pastoris genes in the Saccharomyces Genome Database.

${ }^{\mathrm{b}} \mathrm{Aft} 2$ matrix.

cAft1 matrix.

Upstream binding sites (UBS): $5^{\prime} \rightarrow 3^{\prime},-1000$ to -1 A(0)TG. The core binding sequences, representing the highest conserved, consecutive positions are highlighted. TFBS analysis: MatInspector [18] using the search groups fungi and general core promoter elements. 
P. pastoris Aft1 binding sites were predicted for the regulatory regions of Pdi1 and $\mathrm{BiP}$, two important ER chaperones, indicating that Aft1 is involved in oxidative protein folding. Consistently, Blaiseau et al. [7] showed S. cerevisiae Aft2 involved in oxidative stress resistance. Also, the chaperone Ssa4 and the serine/threonine kinase Kin2, both recently identified as secretion enhancing factors [3], were found to have an upstream Aft1 binding site, confirming Aft1 as an interesting candidate for improving recombinant protein secretion in $P$. pastoris. In addition, Aft1 binding was predicted for the promoter region of $N C P 1$, suggesting that Aft1 is also involved in lipid metabolism [22].

\section{Prediction of Aft1 binding sites in the $P$. pastoris genome}

To elucidate the function of Aft1 in $P$. pastoris, Regulatory Sequence Analysis Tools [23] was used to search for putative Aft1 binding sites in $P$. pastoris promoters. Using the binding motifs known for $S$. cerevisiae Aft1/2, ANTGCACCC and BRCACCCB, resulted in 972 genes with a putative Aft binding site. Thereof, 561 were found annotated [24] and mapped to broader parent terms, GO slim terms, using AmiGO GO Slimmer [25]. Aft1 was found involved in the regulation of approximately 100 different biological processes (Additional file 1), including nucleobase-containing small molecule metabolic processes (57 hits), carbohydrate metabolic processes (50 hits), transcription from RNA polymerase II promoter (47 hits) or amino acids metabolic processes (47 hits). Interestingly, within the categories ion transport (20 hits) and cellular ion homeostasis ( 11 hits) only 6 proteins with a possible connection to iron regulation were found: Ccc1, mediating transfer of iron from cytosol to vacuole [26]; Gef1, a chloride channel localized to the Golgi or endomembrane system, which has also been reported to be governing iron-limited growth [27]; Hmx1, a heme oxygenase, required for the reutilization of iron from heme, also involved in oxidative stress resistance [28,29] and Nfu1, a protein involved in mitochondrial iron sulfur cluster assembly [30]. Notably, none of these are characteristic iron regulatory genes such as the iron reductases FRE1-6 or the multicopper oxidases FET3/5. However, a putative Aft1 binding site was found within the upstream region of FEP1, the GATA type repressor, which has been shown to negatively control iron uptake/homeostasis in $P$. pastoris [16]. Thus, though no Aft1 binding site was found within the upstream region of characteristic iron regulators, the presence of such within the upstream region of FEP1 raises the possibility of a latent, indirect involvement of Aft1 in P. pastoris iron regulation.

Analysing possible other functions of $P$. pastoris Aft1, a high number of biological processes related to the cellular secretory pathway machinery was found (Table 2). 23 gene hits were found for protein targeting, 19 for Golgi to vesicle transport, 12 for response to oxidative
Table 2 P. pastoris genes with putative Aft 1 binding site (s) related to the cellular secretory pathway machinery

\begin{tabular}{ll}
\hline GO slim term - Biological process & Number (Genes) \\
\hline G0:0006605 protein targeting & 23 (ATG1 ATG12 ATG18 GET3 \\
& GET4 IMP2 KAR2 LHS1 NPL6 \\
& NUP188 NUP84 PAM17 PEX14 \\
& PEX7 PEX8 SEC61 SPC1 SPC3 \\
& TAM41 VPS21 VPS64 VPS68 VPS8) \\
& 19 (AGE2 APL4 CHS5 DRS2 EMP24 \\
& GET3 GOS1 HRR25 KES1 SEC12 \\
G0:0048193 Golgi vesicle transport & SEC23 SFB3 SNC2 SVP26 TED1 \\
& TLG1 TRS31 VTI1 YPT32) \\
& 12 (AFT1 CTA1 EOS1 GCY1 GSH1 \\
G0:0006979 response to oxidative & HMX1 HSP104 MXR1 POS5 TSA1 \\
stress & YAP1 YBL055C) \\
G0:0006457 protein folding & 11 (CAJ1 CCT2 CCT6 CPR6 EGD2 \\
& ERV2 HL1 HSP104 PDI1 SIS1 TSA1) \\
G0:0006486 protein glycosylation & 10 (ALG7 EOS1 KRE5 MNN11 OCH1 \\
& OST6 PMT1 PMT5 STT3 SVP26) \\
G0:0016050 vesicle organization & 10 (EMP24 GOS1 SEC12 SEC23 \\
& SFB3 SNC2 TLG1 UBC1 VPS4 VTI1) \\
GO:0007033 vacuole organization & 9 (ATG1 ATG12 ENO1 GYP7 RDI1 \\
& TPM2 VPS21 VTI1 YHC3) \\
G0:0051049 regulation of transport & 9 (AKL1 ARG81 CUP9 FPK1 GEF1 \\
& SEC12 SEC23 SLG1 TUP1) \\
G0:0006887 exocytosis & 6 (ARG81 KES1 KIN1 SNC2 \\
& TPM2 YPT32) \\
\hline
\end{tabular}

Search field: -1000 bp upstream of the $P$. pastoris GS115 coding sequences. Binding motifs: ScAft1 (ANTGCACCC) and ScAft2 (BRCACCCB). Gene hits were categorized into biological function GO terms using AmiGO GO Slimmer (Yeast GO slim set, [25]).

stress, 11 for folding, 10 for glycosylation and vesicle organization, 9 for vacuole organization and regulation of transport, and 6 for exocytosis. Additionally to the already discussed ER chaperones Pdi1 and BiP, several important secretory regulators were identified. Sec12 and Sec23, both involved in COPII vesicle formation and ER to Golgi transport [31], Sec61, forming a channel for protein translocation into and out of the ER [32], Gos1, a v-SNARE protein found to be involved in ER to Golgi and/or intra-Golgi transport [33], Yap1, a transcription factor involved in oxidative stress response [34], Och1, a Golgi resident mannosyltransferase initiating the hypermannosylation of glycoproteins [35] and Kin1, a protein kinase involved in exocytosis [36], were found to possess a putative upstream Aft1 binding site. In accordance with the above-mentioned data, an Aft 1 binding site was found in the upstream region of several genes conferring resistance to oxidative stress, such as YAP1 or $H M X 1$, supporting the hypothesis of a role of Aft1 in oxidative protein folding and/or stress response.

\section{P. pastoris Aft1 has a conserved Aft-domain, but does not} contain the iron-responsive motif

The amino acid sequence of $P$. pastoris (Pp) Aft1 was compared to $S$. cerevisiae (Sc) Aft1/2 and Kluyveromyces 
lactis (K1) Aft using ClustalW2 [37]; all of these proteins display the positive mode of regulation and the characteristic residues Leu99, Leu102, Cys291 and Cys293 conferring iron sensitivity (numbering based on ScAft1, [14]). Interestingly, the $P$. pastoris $\mathrm{N}$-terminal sequence is 41-98 amino acids shorter, lacking the conserved residues Leu99 and Leu102 (PpAft1: Met1, Ile4; Figure 1). Also the residues Cys291 and Cys293 were not found conserved in the P. pastoris sequence (PpAft1: Ser180, Ser182), suggesting a role different from iron regulation for PpAft1. Still, also regions of high homology were found in the N-terminal part of the P. pastoris protein, particularly the Aft-domain (supposedly the DNA binding domain [38]) between the amino acids 10-130. Especially high conservation was found for the residues 10-45 (identity $53 \%$ ) and $102-130$ (identity $45 \%$ ), including the two conserved cysteines and histidines, which have been suggested to be part of a WRKY-motif involved in zinc binding $[14,39]$. Regarding nuclear export, no conservation was found for Ser210 in P. pastoris (PpAft1: Arg97) and K. lactis (KlAft: Gly224), but Ser224 is conserved in all 4 sequences (PpAft1: Ser111, KlAft: Ser238). However, as Ueta et al. [13] showed that individual serine mutations did not affect ScAft1 localization, export via Msn5p seems still possible for PpAft1 and KlAft. In contrast to ScAft1 and KlAft, a glutamine-rich region was found not at the C-terminal end, but between the residues 164-177. This glutamine-rich region is followed by serine (aa 180-213) and asparagine repeats (aa 216-269), maybe as part of a protein-protein interaction domain [40]. No homology was found for the C-terminal part of the PpAft1 protein (identity $<1 \%$ ), in particular the residues 162 to 363 . Interestingly, with only 363 amino acids PpAft1 is considerably shorter than ScAft1 (690 aa), ScAft2 (416 aa) and KlAft (823 aa).

PpAft1 was further compared to C. albicans Aft [NCBI protein: XP_714862], which also lacks the characteristic residues Leu99, Leu102, Cys291 and Cys293. Similar to $P$. pastoris, in C. albicans iron regulation was shown to be under control of a GATA-type repressor [17]. Sequence comparison of these two proteins revealed only one short $\mathrm{N}$-terminal region of high homology between the residues 3-47 (identity 67\%, data not shown). This region was also found to be highly similar in ScAft1/2 and KlAft. Additionally, we searched the genome of the genetically and biochemically close methylotrophic yeast Hansenula polymorpha for a homolog of PpAft1. The protein encoded by HPODL_04658 in H. polymorpha (NCBI protein: ESX01890) has high N-terminal sequence homology including the two conserved cysteines und histidines (aa 3-132: identity 55\%, Additional file 2). A region of high similarity was also found between the residues 244-332 (identity 31\%), suggesting that HPODL_04658 functions similar to PpAft1. As PpAft1 and CaAft, also HPODL_04658 lacks the characteristic iron sensitivity residues. Accordingly, we also found a homolog of the GATA-type repressor in the H. polymorpha genome (HPODL_03720; 48\% sequence identity to PpFep1). In summary, Aft homologs from species that are known to contain also a Fep1-like GATA type repressor (C. albicans, Pichia stipitis, Debaryomyces hansenii according to [14] and H. polymorpha) share high sequence homology to PpAft1 in the N-terminal DNA binding region, but lack the characteristic residues that are conferring iron sensitvity in ScAft1/2 (data not shown). Interestingly, all these species possess another protein of unknown function having a domain with sequence similarity to parts of the Aft DNA-binding domain, but low similarity to ScAft $1 / 2$ (i.e. less than $15 \%$ overall identity).

\section{The $P$. pastoris Aft1 regulon}

To investigate if $P$. pastoris Aft 1 is involved in iron regulation, we generated an AFT1 overexpression (AFT1$\mathrm{OE})$ and an $\Delta$ aft1 disruption mutant, and tested their growth in low and high iron containing media. AFT1OE was achieved by expressing an additional copy of AFT1 under control of its native promoter (see below), while the $\Delta a f t 1$ strain was generated by exchanging parts of the gene for the KanMX marker cassette using the split marker approach as described by Heiss et al. [41]. Low iron media was prepared by addition of the iron chelator BPS (bathophenanthroline disulphonate) to YPD or YNB-Glucose agar plates as described by Miele et al. [16]. In order to exclude the possibility to be outside the sensitivity range we tried several concentrations of BPS in the iron sensitivity assay. Miele et al. [16] reported the use of YPD containing 80-160 $\mu \mathrm{M}$ BPS for $P$. pastoris. We tested concentrations ranging from 80-200 $\mu \mathrm{M}$ BPS in YP and minimal medium (YNB or M2) using either glucose or methanol as carbon source. We did not observe growth impairment of $P$. pastoris CBS7435 wild type using $80 \mu \mathrm{M}$ BPS in YPD or YPM (data not shown). When using higher BPS concentrations, growth of all strains was significantly delayed. However, we did not observe differences between the $\triangle$ aft1 strain, the AFT1-OE and the wild type control on any of the media tested (Figure 2). Thus, disruption of AFT1 does not render $P$. pastoris sensitive to ironlimited conditions. This behaviour is contrary to the phenotype observed for $\Delta a f t 1 / 2$ in $S$. cerevisiae and $\Delta$ aft 1 in K. lactis, which grow only poorly or are unable to grow in the same low iron conditions $[7,14]$, suggesting that $P$. pastoris Aft1 is not involved in iron regulation. Additionally, the $P$. pastoris $\Delta$ aft 1 mutant did not show impaired growth on the cell wall disturbing agent Calcofluor White, which is again in contrast to what is reported for S. cerevisiae $\Delta$ aft1 (not shown). 
(See figure on previous page.)

Figure 1 Aft1 protein sequence comparison. Amino acid sequences: S. cerevisiae Aft1 [NCBI protein: NP_011444] and Aft2 [NCBI protein: NP_015122], K. lactis Aft [NCBI protein:CAH00307], and P. pastoris Aft1 [NCBI protein:CCA37276] were aligned using ClustalW2 [37]. asterisk: "indicates positions which have a single, fully conserved residue", colon: "indicates conservation between groups of strongly similar properties"; period: "indicates conservation between groups of weakly similar properties"; shaded grey: conserved residues (Leu99*, Leu102, Cys291 and Cys293 conferring iron sensitivity. Ser210 and Ser224 involved in Msn5 recognition and nuclear export. Cys143, Cys215, His239 and His241, which are suggested to be part of a WRKY-motif involved in zinc binding [39]). Differences are boxed and/or highlighted red; *numbering is based on ScAft1.

In order to identify the regulon of Aft1 in P. pastoris, we analysed the transcription patterns of the $\Delta$ aft 1 strain and control using DNA microarrays. All strains were cultivated in synthetic minimal medium with glucose feed beads for $5 \mathrm{~h}$ in three biological replicates. Interestingly, although Aft-like proteins are described as transcriptional activators, an even higher number of genes was up-regulated (54 genes, 33 thereof more than 1.5fold) than down-regulated (34 genes, 13 thereof more than 1.5 -fold) in the $\Delta a f t 1$ mutant compared to the wild type (an adjusted p-value of $<0.05$ was applied as cut-off to identify significantly regulated genes, Additional file 3 ). $42 \%$ of the up-regulated and $38 \%$ of the downregulated genes contain at least one putative Aft 1 binding site in their promoters (compared to $18 \%$ of total $P$. pastoris genes), suggesting that both, up- and downregulation, are a direct consequence of AFT1 disruption. Table 3 summarizes differentially regulated genes in the $\Delta$ aft 1 mutant compared to the wild type strain according to their GO term category.

In the $\Delta a f t 1$ strain, 9 putative transcriptional regulators are among the regulated genes, seven of them carrying putative Aft1 binding sites in their promoters. PAS_chr4_0324, a fungal specific transcription factor of unknown function with a Zn2/Cys6 DNA-binding domain is the highest up-regulated gene, while MIG1-1, encoding a transcription factor connected to glucose repression, has lower expression levels in the $\Delta$ aft $1 \mathrm{mu}-$ tant. Most other regulated transcription factors are also of the fungal-specific Zn2/Cys6 type, but lack annotated function and defined target genes. Furthermore, 23 of the 54 up-regulated and 9 of the 34 down-regulated genes encode hypothetical proteins of unknown function. The second largest group of regulated genes comprises transport proteins, mainly transmembrane transporters, however, there is no clear preference for transported substrates, which range from ions to polyamines and sugars.

Regarding iron regulation, no changes in transcript levels were observed for the GATA-type repressor FEP1, in line with the unaltered expression levels of genes involved in iron uptake and homeostasis (i.e. FRE1-6 or FET3/FET5). Re-analysis of our previous microarray data (obtained in different environmental conditions, [42,43]) for expression changes of iron regulatory genes indeed

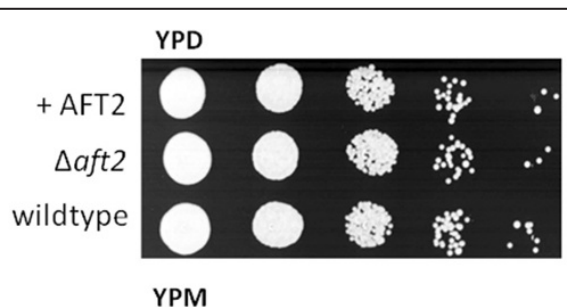

YPD $+200 \mu \mathrm{M}$ BPS
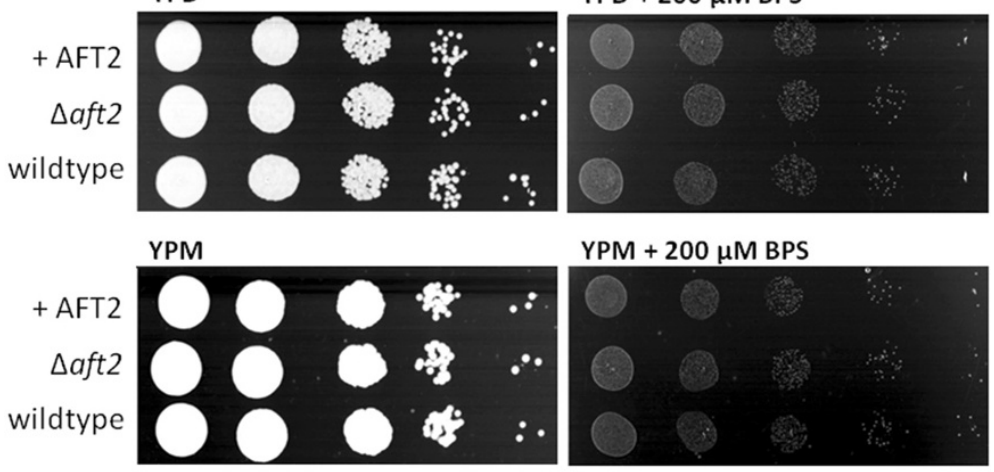

YPM + $200 \mu \mathrm{M}$ BPS
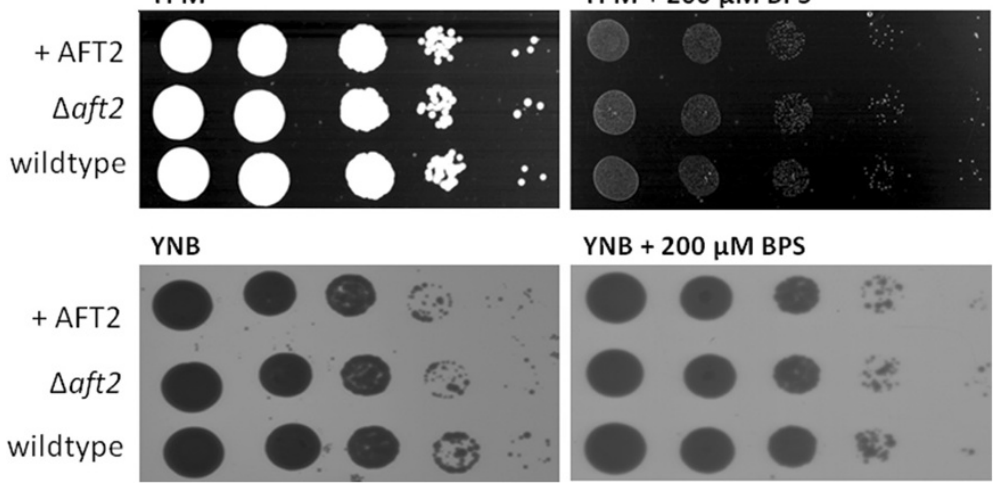

YNB $+200 \mu \mathrm{M}$ BPS

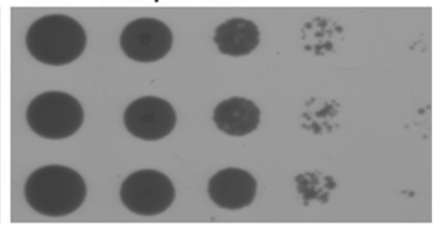

Figure 2 Spotting assay on iron deficient media. Serial 1:10 dilutions of $P$. pastoris CBS7435 wild type, AFT1-OE and $\Delta$ aft 1 cell suspensions were spotted on YP plates containing either $2 \%$ glucose or $1 \%$ methanol as carbon source and on YNB agar plates containing $2 \%$ glucose as carbon source. Iron-deficient conditions were generated by addition of the iron chelator BPS (200 $\mu \mathrm{M})$. Plates were incubated at $28^{\circ} \mathrm{C}$ for $70 \mathrm{~h}$. While addition of BPS resulted in generally delayed growth on both substrates, no difference between the strains was seen. 
Table 3 Differentially expressed and annotated genes in the $\Delta a f t 1$ vs. control (wild type) strain

Up-regulated genes ( $\Delta$ aft 1 vs. control)

GO slim term - Biological process Number (Genes)

GO:0006811 ion transport

7 ( AQR1 ATX1 GEF1 MEP2

TPO3 YHLO08C ZRT1 )

GO:0008150 biological_process*

6 ( ECM13 GPM3 YELO23C YLR156C-A YLR278C YOR292( )

GO:0055085 transmembrane transport 6 ( AQR1 GEF1 MEP2 STL1 TPO3 ZRT1 )

GO:0006366 transcription from RNA polymerase II promoter

GO:0042221 response to chemical

GO:0006520 cellular amino acid metabolic process

GO:0007124 pseudohyphal growth

GO:0051186 cofactor metabolic process

GO:0005975 carbohydrate metabolic process

GO:0006091 generation of precursor metabolites and energy

GO:0006766 vitamin metabolic process

GO:0006873 cellular ion

homeostasis

GO:0055086 nucleobase-containing small molecule metabolic process

GO:0001403 invasive growth

in response to glucose

limitation

GO:0002181 cytoplasmic

translation

GO:0006325 chromatin

organization

GO:0006397 mRNA

processing

GO:0006470 protein

dephosphorylation

GO:0006629 lipid metabolic

process

GO:0006865 amino acid

transport

GO:0006979 response to oxidative stress

GO:0007005 mitochondrion

organization

GO:0008033 tRNA processing

GO:0008643 carbohydrate transport

GO:0070647 protein modification

by small protein conjugation or removal

5 ( GCR1 PHD1 RPM2 UGA3 YLR278C)

5 ( AQR1 ATX1 GCR1 SLII UGA3)

4 ( ADH2 ECM4 SFA1 UGA3)

4 ( HMS1 MEP2 PHD1 PTP1)

4 ( ADH2 ALD4 BIO2 THI21)

3 ( DOG1 GCR1 GPM3 )

2 ( GCR1 GPM3 )

2 ( BIO2 THI21)

$2($ ATX1 GEF1)

$2(A D H 2$ ALD4 )

1 ( PTP1)

1 ( RPM2)

1 ( GCR1)

1 ( RPM2)

1 ( PTP1)

1 (YJU3)

$1(A Q R 1)$

$1(\operatorname{ATX1})$

$1($ RPM2)

1 ( RPM2)

1 ( STL1)

$1(\mathrm{PCl})$
Table 3 Differentially expressed and annotated genes in the $\Delta$ aft 1 vs. control (wild type) strain (Continued)

\begin{tabular}{|c|c|}
\hline \\
\hline GO slim term - Biological process & $\begin{array}{l}\text { Down-regulated genes ( } \Delta \text { aft1 vs. control) } \\
\text { GO slim term - Biological process Number (Genes) }\end{array}$ \\
\hline GO:0006811 ion transport & 4 ( ATO2 JEN1 TAT2 VMA8) \\
\hline GO:0055085 transmembrane transport & 4 ( ITR1 JEN1 PEX13 TAT2) \\
\hline GO:0006281 DNA repair & $3($ PCD1 RVB1 YRA1) \\
\hline GO:0006325 chromatin organization & $3($ ACS1 RLF2 RVB1) \\
\hline $\begin{array}{l}\text { GO:0006366 transcription from RNA } \\
\text { polymerase II promoter }\end{array}$ & $3($ MIG1 RVB1 YHP1) \\
\hline $\begin{array}{l}\text { GO:0006974 cellular response to DNA } \\
\text { damage stimulus }\end{array}$ & $3(P C D 1$ RVB1 YRA1) \\
\hline GO:0008150 biological_process* & 3 ( NBA1 TOS8 YHR177W ) \\
\hline $\begin{array}{l}\text { GO:0005975 carbohydrate metabolic } \\
\text { process }\end{array}$ & 2 ( CTS1 MIG1) \\
\hline $\begin{array}{l}\text { GO:0006766 vitamin metabolic } \\
\text { process }\end{array}$ & $2($ SNO1 SNZ3 ) \\
\hline $\begin{array}{l}\text { GO:0051186 cofactor metabolic } \\
\text { process }\end{array}$ & $2($ ACS1 SNZ3 ) \\
\hline $\begin{array}{l}\text { GO:0055086 nucleobase-containing } \\
\text { small molecule metabolic process }\end{array}$ & $2(P C D 1$ YRA1 $)$ \\
\hline $\begin{array}{l}\text { GO:0070271 protein complex } \\
\text { biogenesis }\end{array}$ & $2($ PEX13 RLF2) \\
\hline GO:0000278 mitotic cell cycle & $1($ YHP1 $)$ \\
\hline GO:0000910 cytokinesis & 1 ( CTS1) \\
\hline GO:0002181 cytoplasmic translation & $1(R P L 4 A)$ \\
\hline $\begin{array}{l}\text { GO:0006091 generation of precursor } \\
\text { metabolites and energy }\end{array}$ & $1(A C S 1)$ \\
\hline $\begin{array}{l}\text { GO:0006520 cellular amino acid } \\
\text { metabolic process }\end{array}$ & $1($ SNO1 ) \\
\hline GO:0006605 protein targeting & $1($ PEX13) \\
\hline GO:0006865 amino acid transport & $1($ TAT2 $)$ \\
\hline GO:0006873 cellular ion homeostasis & $1($ VMA8) \\
\hline GO:0007031 peroxisome organization & $1($ PEX13) \\
\hline GO:0008643 carbohydrate transport & 1 ( JEN1 ) \\
\hline $\begin{array}{l}\text { GO:0015931 nucleobase-containing } \\
\text { compound transport }\end{array}$ & $1($ YRA1 $)$ \\
\hline GO:0016570 histone modification & $1($ ACS1) \\
\hline $\begin{array}{l}\text { GO:0018193 peptidyl-amino acid } \\
\text { modification }\end{array}$ & $1($ ACS1) \\
\hline GO:0042221 response to chemical & $1($ MIG1) \\
\hline GO:0042594 response to starvation & $1($ MIG1) \\
\hline GO:0043543 protein acylation & $1($ ACS1) \\
\hline GO:0048193 Golgi vesicle transport & $1(B R E 5)$ \\
\hline GO:0051049 regulation of transport & $1($ BRE5 ) \\
\hline GO:0051169 nuclear transport & $1($ YRA1 ) \\
\hline $\begin{array}{l}\text { GO:0070647 protein modification by } \\
\text { small protein conjugation or removal }\end{array}$ & $1($ BRE5 ) \\
\hline
\end{tabular}

*Biological process is unkown.

Genes were categorized into biological function GO terms using AmiGO GO Slimmer (Yeast GO slim set, [25]). 
revealed that induction of the iron regulon is dependent on the levels of FEP1, but not AFT1 in P. pastoris.

Notably, Atx1 and Gef1, which were described to be required for the correct assembly of the high affinity iron transporter Fet3 in S. cerevisiae, were found among the up-regulated genes in the $\Delta a f t 1$ mutant, pointing towards a different regulation of iron acquisition genes in P. pastoris.

Among the up-regulated genes several genes which are described to be repressed by glucose in S. cerevisiae are found, including alcohol dehydrogenase $A D H 2$ and the two putative mitochondrial aldehyde dehydrogenases ALD4-1 and ALD5. All of these contain putative Aft1 binding sites in their promoter regions. Interestingly, deletion of these gene functions has recently been predicted by the genome scale metabolic model of $P$. pastoris to enhance recombinant protein production [44]. Moreover, carbon-source responsive transporters of the multifacilitator superfamily are among the regulated genes in the $\Delta$ aft 1 mutant. While the genes encoding the high affinity glucose transporter Ght1 and the putative glycerol transporter PAS_c034_0021 are upregulated in the $\Delta$ aft 1 mutant, the second high affinity glucose transporter of $P$. pastoris, encoded by GHT2 as well as a homolog of the S. cerevisiae myo-inositol transporter ITR1, are repressed in this strain. This implicates that Aft1 is involved in the regulation of glucoserepressed genes, at least in an indirect manner by regulating MIG1-1 expression, but maybe also directly as some of these genes also contain Aft1 binding sites in their promoters. In this respect, it should be noted that AFT1 expression levels are significantly higher not only in glucose-limited conditions, but also in cells grown on methanol as compared to glucose or glycerol surplus (see below and own unpublished data). A correlation of $A F T 1 / 2$ expression levels and the carbon source has also been observed in S. cerevisiae, where differences between the fermentable carbon source glucose and the non-fermentable carbon source glycerol were reported [38].

\section{Regulation of the $P$. pastoris AFT1 promoter}

To study the expression strength of the natural AFT1 promoter and to test if it is applicable for overexpression studies, intracellular expression of green fluorescent protein was analysed (cycle-3-GFP, [45]). 96-well deep-well plate screening, which has been applied for $P$. pastoris promoter studies before [46], was used for cultivation. However, the protocol was adjusted for GAP promoter driven expression, which was used for the expression of our model protein carboxylesterase.

$P$. pastoris was transformed with plasmid pPpKan$\mathrm{S}$-GFP. Clones expressing GFP from the AFT1 promoter were studied for intracellular fluorescence levels in comparison to clones expressing GFP from the constitutive GAP promoter. On average, the tested $\mathrm{P}_{A F T 1}$ clones reached 724 relative fluorescence units (RFU) after $69 \mathrm{~h}$ of cultivation, which was $60 \%$ in comparison to the respective $\mathrm{P}_{G A P}$ clones. In terms of average yields, the $\mathrm{P}_{A F T 1}$ clones reached $343 \mathrm{RFU} \mathrm{OD}{ }^{-1}$, corresponding to $50 \%$ of the yield of the $\mathrm{P}_{G A P}$ clones, characterising $\mathrm{P}_{A F T 1}$ as fairly strong promoter under the conditions tested. Analysing expression at 24, 48 and $69 \mathrm{~h}$ of cultivation, differences in regulation were observed. While the $\mathrm{P}_{G A P}$ clones showed the expected constitutive expression profile with stable titers of $1201 \pm 64$ RFU at the different time points, $\mathrm{P}_{A F T 1}$ controlled expression significantly increased with longer cultivation times, reaching a maximum at $69 \mathrm{~h}$ of cultivation (Figure 3A). Assuming that the observed effect was related to a decrease in glucose concentration, a batch series starting with 1, 2 and $4 \%$ glucose was studied for about $48 \mathrm{~h}$ (data not shown). The results confirmed enhanced $\mathrm{P}_{A F T 1}$ activity at lower

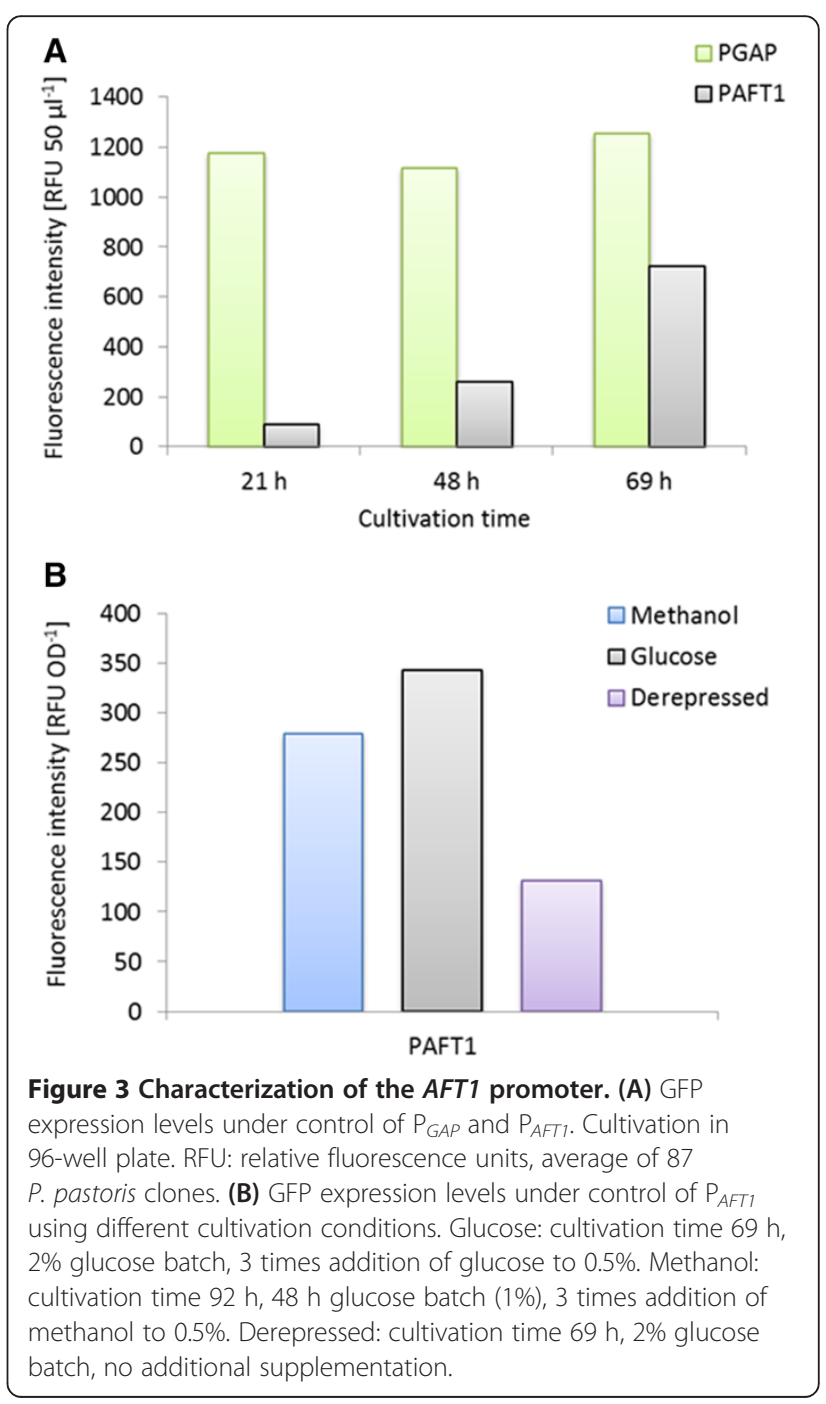


glucose concentrations, showing average yields of 104, 81 and only 16 RFU OD ${ }^{-1}$, for the 1,2 and $4 \%$ glucose batches, respectively.

Interestingly and matching above data, the AFT1 promoter was also found inducible by methanol, reaching $80 \%\left(280 \mathrm{RFU} \mathrm{OD}{ }^{-1}\right)$ of the yield of glucose cultivated cells (Figure $3 \mathrm{~B}$ ). In comparison, using a $2 \%$ glucose batch without supplementation (derepressed protocol), a yield of only $40 \%$ was reached. While $\mathrm{P}_{A F T 1}$ is obviously a rather strong and also methanol-inducible promoter, unlimited access of glucose negatively affects $\mathrm{P}_{A F T 1}$ activity and presumably decreases overexpression effects.

\section{The effect of AFT1 overexpression on the secretion of recombinant proteins}

Although none of the secretion-related genes was differentially expressed in the $\Delta$ aft1 mutant under the analysed conditions, our next step was to analyse whether AFT1 overexpression influences the secretion of recombinant proteins. Our model protein of choice was a carboxylesterase from Sphingopyxis sp. MTA144. This carboxylesterase is under development for use as a feed additive enzyme, because it hydrolyses an antinutritive substance that may be naturally contained in animal feed [47]. P. pastoris has recently been shown to secrete active carboxylesterase [48]. However, for a technological application of this carboxylesterase as feed enzyme for gastrointestinal detoxification in animals, a high yield recombinant production process is required.

\section{Generation of carboxylesterase secreting strains}

Carboxylesterase secreting strains were generated by transformation of $P$. pastoris CBS7435 with plasmid pPM2dZ30PGAP $\alpha-C E$ expressing carboxylesterase under control of the GAP promoter and using the $S$. cerevisiae alpha mating factor signal sequence as secretion leader. Carboxylesterase represented the major fraction of total secreted protein of each transformant, yielding a strong band at the calculated size of $52 \mathrm{kDa}$. However, due to varying numbers of integrated expression cassettes, strains secreting lower and higher levels of carboxylesterase were observed (Additional file 4). The best-secreting strain CE\#18 contained 6 copies of the expression cassette, while the average strain CE\#12 had only one expression cassette integrated in its genome, confirming a positive correlation between secretion level and gene copy number. Using ELISA, an expression level of $80 \mu \mathrm{g} \mathrm{mL}^{-1}$ was determined for CE\#18, whereas a titer of approximately $20 \mu \mathrm{g} \mathrm{mL}^{-1}$ was determined for strain CE\#12.

\section{AFT1 co-expression studies}

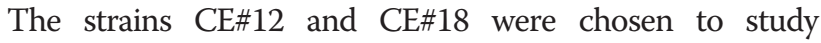
whether overexpression of $A F T 1$ can positively influence recombinant protein secretion. Both strains were transformed with linearized pPM2aK21-AFT1, comprising the AFT1 gene under control of its natural promoter and terminator. Supernatants of 8 transformants of each strain were studied for carboxylesterase secretion after $48 \mathrm{~h}$ of cultivation in shake flask. ELISA was used to reveal small, but significant differences in carboxylesterase secretion levels, showing improved secreting clones for both strain backgrounds. Figure 4 shows the results of the best two clones of each strain. Interestingly, while the best CE\#12-AFT1 clones yielded a strong improvement of $62 \pm 5 \%$, the best two CE\#18-AFT1 strains showed considerably less improvement, reaching an increase of only $19 \pm 6 \%$. However, it has to be considered that strain CE\#18 produced four times more carboxylesterase $\left(80 \mu \mathrm{g} \mathrm{mL}^{-1}\right)$ than strain CE\#12 $\left(20 \mu \mathrm{g} \mathrm{mL}^{-1}\right)$. Assuming that Aft1 is involved in oxidative protein folding, high overproduction of carboxylesterase could have led to an overload of recombinant protein in the ER and subsequent induction of ERAD. Newly elicited upstream or downstream bottlenecks could also be the reason for the reduced influence of AFT1 overexpression and the only modest improvement for strain CE\#18.

The growth behaviour of AFT1 overexpressing strains was studied in addition. In contrast to secretion levels, growth under these conditions was seemingly unaffected by overexpression of $A F T 1$, showing neither significant changes in final OD levels $(<15 \%, 48 \mathrm{~h})$ nor any detectable alteration in the growth curve (data not shown).

\section{Bioreactor cultivations}

To confirm the positive effect of AFT1 overexpression on carboxylesterase secretion, the best strains from screening were studied in bioreactor cultivations. First, the performance of the AFT1 overexpressing strain CE\#12-AFT1-A was compared to the starting strain (CE\#12). Cultivations were performed using aerobic and

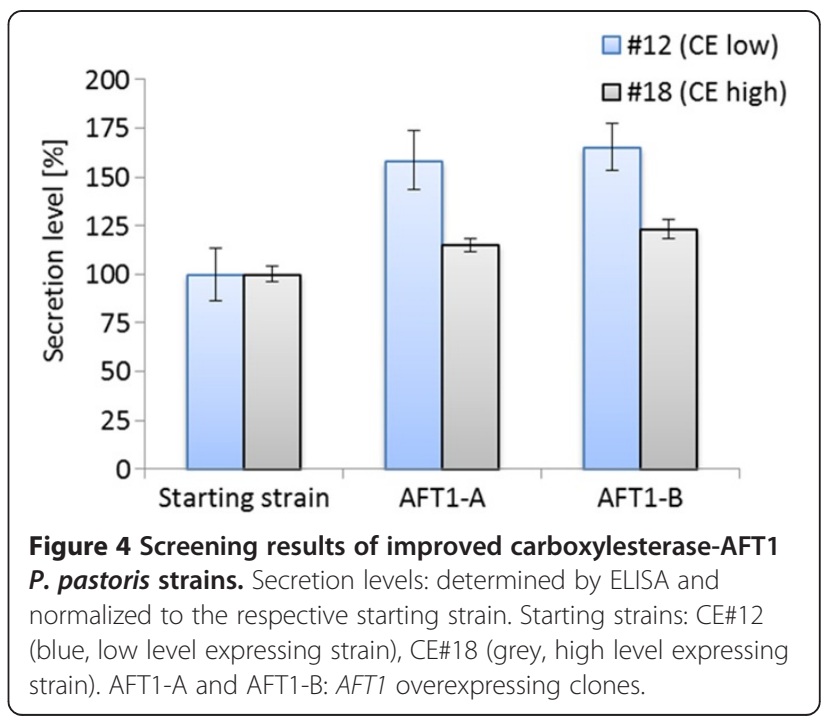


hypoxic production conditions as preceding bioreactor experiments had indicated that a low oxygen supply is beneficial for carboxylesterase secretion (data not shown), an observation that had also been made for the production of antibody Fab fragments and trypsinogen [49]. While under aerobic production conditions a dissolved oxygen (DO) concentration of $20 \%$ was maintained throughout the whole process, a DO level of 5\% was applied during the feed phase for hypoxic conditions. Bioreactor cultivations were monitored for $100 \mathrm{~h}$. In addition to the quantification of secreted recombinant carboxylesterase by SDS-PAGE, also the functional quality of the enzyme was assessed by an activity assay.

The positive effect of AFT1 overexpression on the secretion rate of strain $\mathrm{CE} \# 12$ was indeed confirmed in bioreactor. A maximum of $141 \mathrm{U} \mathrm{L}^{-1}$ was reached for strain CE\#12-AFT1-A after $100 \mathrm{~h}$ of cultivation under hypoxic conditions, while the starting strain reached only a level of $76 \mathrm{U} \mathrm{L}^{-1}$ at this time point (Figure 5A). Confirming the beneficial effect of hypoxic production conditions, carboxylesterase activity levels were 3-4 fold lower under aerobic conditions. Applying $20 \%$ DO, a maximum of only $37 \mathrm{U} \mathrm{L}^{-1}$ was reached for strain CE\#12-AFT1-A after $100 \mathrm{~h}$ of cultivation. However, comparing to the starting strain under the same conditions a 2.5 -fold higher activity level was achieved for the AFT1 overexpressing strain. It seems that the amount of dissolved oxygen does not abrogate the beneficial impact of AFT1 overexpression on carboxylesterase secretion. As observed previously [43], lower amounts of biomass were reached in hypoxic compared to normoxic conditions due to the production of ethanol at the low DO setpoint. Consistently, about 2-fold higher carboxylesterase yields ( $\mathrm{U} \mathrm{g}^{-1}$ biomass) were obtained for the AFT1 overexpressing strain under both conditions. The results of the activity assays were confirmed by SDSPAGE (Figure 5B). Comparing to a bovine serum albumin (BSA) standard, a carboxylesterase protein level of about $0.75 \mathrm{~g} \mathrm{~L}^{-1}$ was estimated for strain CE\#12-AFT1-A after $100 \mathrm{~h}$ of cultivation under hypoxic conditions, while the starting strain produced below $0.5 \mathrm{~g} \mathrm{~L}^{-1}$ until this time point.

Also the performance of the multi-copy carboxylesterase AFT1 overexpressing strain CE\#18-AFT1-A was investigated in bioreactor under hypoxic conditions (Figure 5C). Again the positive effect of $A F T 1$ overexpression was confirmed. Strain CE\#18-AFT1-A reached $169 \mathrm{U} \mathrm{L}^{-1}$ after $74 \mathrm{~h}$ of cultivation, while the starting strain (CE\#18) only reached $133 \mathrm{U} \mathrm{L}^{-1}$ at the same time point. As before, results were confirmed by SDS-PAGE, showing increased protein levels for strain CE\#18-AFT1-A after 74 and $98 \mathrm{~h}$ of cultivation (Figure 5D). Comparing yields, secretion per biomass was increased 24\% for strain CE\#18-AFT1-A. The AFT1 overexpressing strain also yielded 25\% higher ethanol levels, reconfirming the involvement of $P$. pastoris Aft1 in carbon-responsive regulation.

The AFT1 copy number of the overexpressing strains was also investigated. RT-PCR revealed one AFT1 overexpression cassette for strain CE\#12-AFT1-A and three for strain CE\#18-AFT1-A. Notably, strain CE\#18-AFT1-

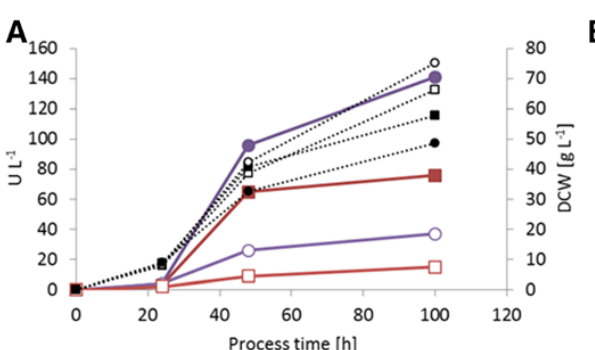

B

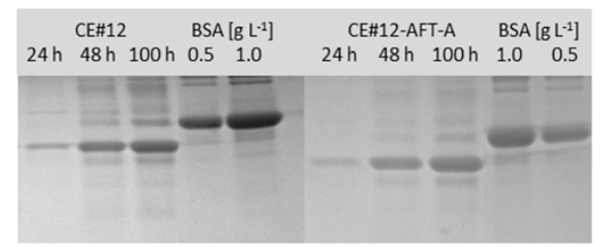

c

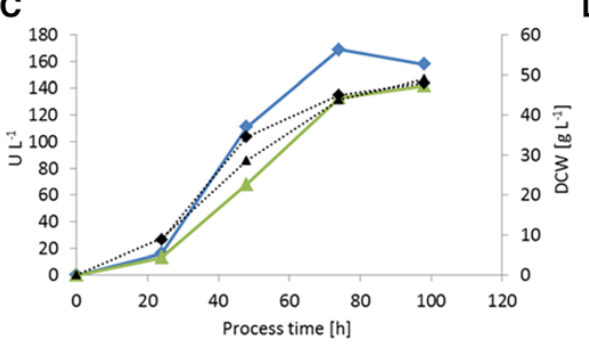

D

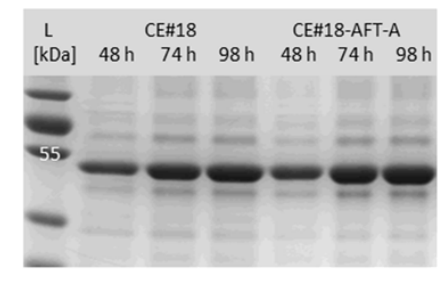

Figure 5 Bioreactor cultivations of improved carboxylesterase-AFT1 P. pastoris strains. (A) Carboxylesterase activity levels $\left(U L^{-1}\right)$ of strain CE\#12 (red squares) and strain CE\#12-AFT1-A (purple circles). Closed symbols: hypoxic conditions; open symbols: aerobic conditions. (C) Carboxylesterase activity levels ( $\left.U L^{-1}\right)$ of strain CE\#18 (green triangles) and strain CE\#18-AFT1-A (blue rhomboids). Dashed lines: biomass values (DCW, $\mathrm{g} \mathrm{L}^{-1}$ ). (B) and (D) Reducing SDS-PAGE of supernatant samples from different cultivation time points (hypoxic conditions). BSA: bovine serum albumin standard (66.5 kDa). 
B, which had only one AFT1 overexpression cassette integrated, did not show superior behaviour in bioreactor (data not shown). Seemingly, several AFT1 expression cassettes are necessary to positively influence the secretion of the high-level carboxylesterase producer \#18, which might allow for further improvement by targeted AFT1 copy number amplification or the use of stronger promoters for AFT1 overexpression.

Both carboxylesterase-strains, CE\#12 and CE\#18, were also transformed with an empty vector control plasmid (pPM2aK21-empty). However, carboxylesterase secretion levels were not influenced, neither in shake flask (CE\#12empty) nor in bioreactor cultivations (CE\#18-empty).

\section{Conclusions}

By analysing the promoter regions of secretion enhancing $P$. pastoris genes, the ortholog of the $S$. cerevisiae iron regulators $\mathrm{Aft} 1 / 2$ was selected as a novel factor to improve recombinant protein secretion. A genome-wide analysis of putative Aft1 binding sites in P. pastoris showed Aft1 to be involved in the regulation of many secretory genes, in addition to genes involved in carbohydrate metabolism. The absence of Aft1 binding sites in iron regulatory genes, i.e. FRE1-6 or FET3/FET5, led us to assume iron-independent functions of Aft 1 in $P$. pastoris. These findings were supported by primary amino acid sequence analysis, showing that the DNA binding domain, but not the iron-responsive motif is conserved in the P. pastoris protein. Using DNA microarrays we unveiled further evidence that Aft1 might not directly be required for iron regulation, but is rather involved in regulatory mechanisms in response to carbon source availability, showing e.g. higher transcriptional activation at low glucose concentrations. We also discovered an involvement of $P$. pastoris Aft1 in the expression of glucose-repressible genes, which needs to be analysed in more detail in future studies. Finally, though microarray data did not reveal differential regulation of any secretion related genes, the secretion enhancing effect of AFT1 was confirmed in overexpressing strains, yielding up to 2.5-fold more secreted carboxylesterase.

\section{Materials and methods}

\section{Strains and plasmids}

P. pastoris wild type CBS7435 (Centraalbureau voor Schimmelcultures, NL) was used as host strain [50]. The plasmid pPpKan-S-GFP for GFP expression was described by Näätsaari et al. ([GenBank:JQ519694], [51]). Plasmid pPM2dZ30-PGAP $\alpha$, a derivative of pPUZZLE [6], was used for the expression of a carboxylesterase from Sphingopyxis macrogoltabida (aa residues 48 to 540, [GenBank: ACS27056]) under control of the P. pastoris GAP promoter, with the $S$. cerevisiae $\alpha$-MF leader sequence for secretion and a Zeocin resistance marker cassette. Prior to transformation, the expression vector was linearized within the GAP promoter using the restriction enzyme $B \ln \mathrm{I}$ for homologous integration into the native GAP promoter locus of the $P$. pastoris genome.

For overexpression of $P$. pastoris AFT1 the pPUZZLE derived plasmid pPM2aK21 was used, which contains the KanMX4 cassette conferring resistance to Kanamycin/ Geneticin (G418), and an $A O X 1$ terminator sequence, which, when linearized with $A s c$ I, provides the homologous stretches for integration into the native $P$. pastoris $A O X 1$ terminator locus. The AFT1 expression cassette, including the $A F T 1$ gene $[P$. pastoris gene identifier: PAS_chr1-4_0361] and 1000 bp up- and 400 bp downstream sequences, was amplified from $P$. pastoris genomic DNA using following primers: ApaI-AFT-fw (AAAGGGC CCCCAGGTGAATGTACGTAATGGAG) and AgeI-AFTrv (TTTACCGGTGGGGAGAAGCCGAATTGGAAG). After ApaI/AgeI digestion, the PCR product was cloned into pPM2aK21, creating pPM2aK21-AFT.

\section{AFT1 gene knock out}

A split marker cassette approach was used as described by Heiss et al. [41] to generate transformants with a disrupted AFT1 gene locus. The AFT flanking regions (A upstream, D downstream) were fused to the G418 resistance cassette fragments $\mathrm{B}$ and $\mathrm{C}$, respectively, by overlap PCR. Then, equal amounts of both split marker fragments ( $A B$ and $C D)$ were pooled and simultaneously transformed into $P$. pastoris. The G418 resistance gene is reconstituted when both split marker fragments integrate at the correct locus. Verification of positive $\Delta$ aft 1 transformant strains was done by PCR using a primer pair designed to bind on the native AFT1 locus up- and downstream of the split-marker cassette on genomic DNA of Geneticin-resistant transformants. Primers and split marker fragment sizes are shown in Additional file 5.

\section{Transformation}

Electrocompetent $P$. pastoris cells were transformed using the following parameters: 1.5-2.0 kV, $25 \mu \mathrm{F}$ and $200 \Omega$. After two hours of regeneration on YP medium, containing $20 \mathrm{~g} \mathrm{~L}^{-1}$ glucose, selection of positive transformants was done by incubation for $48 \mathrm{~h}$ and $28^{\circ} \mathrm{C}$ on YPD agar plates $\left(20 \mathrm{~g} \mathrm{~L}^{-1}\right.$ yeast extract, $10 \mathrm{~g} \mathrm{~L}^{-1}$ peptone, $20 \mathrm{~g} \mathrm{~L}^{-1}$ glucose, $20 \mathrm{~g} \mathrm{~L}^{-1}$ agar-agar) supplemented with antibiotic, $50 \mu \mathrm{g} \mathrm{mL} \mathrm{m}^{-1}$ Zeocin and/or $450 \mu \mathrm{g} \mathrm{mL} \mathrm{m}^{-1}$ Geneticin, respectively.

\section{Media and cultivation}

If not stated otherwise chemicals were purchased from BD, Carl Roth, Merck and Sigma Aldrich. YP medium contained $20 \mathrm{~g}$ peptone and $10 \mathrm{~g}$ yeast extract per liter. Buffered minimal (BM)-medium contained $10 \mathrm{~g}$ yeast extract, $10 \mathrm{~g}$ peptone, $100 \mathrm{mM}$ potassium phosphate 
buffer ( $\mathrm{pH}$ 6.0), $13.4 \mathrm{~g}$ yeast nitrogen base without amino acids and $0.4 \mathrm{mg}$ biotin per liter.

Microscale cultivations for GFP expression were performed in 96-well deep-well plates. $300 \mu \mathrm{L}$ of BMmedium, containing $2 \%$ glucose, were inoculated using a toothpick and incubated at $25^{\circ} \mathrm{C}$ and $360 \mathrm{rpm}$. The culture was supplemented with glucose to $0.5 \%$ at 24 and $36 \mathrm{~h}$ of cultivation. Cells were finally harvested after $69 \mathrm{~h}$ of cultivation. Methanol induced cultivations were carried out based on the protocol of Weis et al. [52]. Cells were grown for $48 \mathrm{~h}$ in $300 \mu \mathrm{L}$ of BM-medium, containing $1 \%$ glucose. Cells were induced by addition of methanol $(0.5 \%)$ after 48,56 and $72 \mathrm{~h}$ of cultivation. Finally, cells were harvested after $92 \mathrm{~h}$ of cultivation.

Shake flask cultivations were performed in $100 \mathrm{~mL}$ shake flasks without baffles. As pre-culture, $2.5 \mathrm{~mL}$ YP medium, containing $2 \%$ glycerol and the respective antibiotic(s), were inoculated in a $50 \mathrm{~mL}$ falcon tube and incubated for a minimum of $24 \mathrm{~h}$ at $25^{\circ} \mathrm{C}$ and $180 \mathrm{rpm}$. The main cultures, containing $10 \mathrm{~mL}$ BM-medium with $2 \%$ glucose, were inoculated to an $\mathrm{OD}_{600}$ of 0.1 . Cultures were then incubated at $25^{\circ} \mathrm{C}$ and $180 \mathrm{rpm}$, and supplemented three times with glucose to $0.5 \%$ in $12 \mathrm{~h}$ intervals. Cells were harvested after 48 h by centrifugation at $4000 \mathrm{rpm}$. Subsequently, supernatants were analyzed for carboxylesterase production and cell pellets were used for cell weight analysis. Alternatively, $\mathrm{OD}_{600}$ was measured.

Pre-cultures for bioreactor cultivations were performed in $500 \mathrm{~mL}$ baffled shake flasks and $50 \mathrm{~mL} \mathrm{YP}$ medium, containing $2 \%$ glucose and $0.01 \mathrm{~g} \mathrm{~L}^{-1}$ Glanapon DG160 (Bussetti). The main medium used for fed batch cultivations was used as described by Zhao et al. [53], supplemented with biotin and Glanapon DG160. The batch medium consisted of $4 \mathrm{~g} \mathrm{~L}^{-1} \mathrm{KH}_{2} \mathrm{PO}_{4}, 4 \mathrm{~g} \mathrm{~L}^{-1}$ $\left(\mathrm{NH}_{4}\right)_{2} \mathrm{SO}_{4}, 0.38 \mathrm{~g} \mathrm{~L}^{-1} \mathrm{CaCl}_{2}, 18.2 \mathrm{~g} \mathrm{~L}^{-1} \mathrm{~K}_{2} \mathrm{SO}_{4}, 9.4 \mathrm{~g} \mathrm{~L}^{-1}$ $\mathrm{MgSO}_{4} 7 \mathrm{H}_{2} \mathrm{O}, 40 \mathrm{~g} \mathrm{~L}^{-1}$ glucose monohydrate (Tereos Syral), $1 \mathrm{~g} \mathrm{~L}^{-1}$ Glanapon DG160 and $1 \mathrm{~mL} \mathrm{~L}^{-1}$ trace element solution. The trace element solution contained $2.50 \mathrm{~g} \mathrm{~L}^{-1} \mathrm{MnSO}_{4} \mathrm{H}_{2} \mathrm{O}$ (Riedel-de-Haën), $54.17 \mathrm{~g} \mathrm{~L}^{-1}$ $\mathrm{FeSO}_{4} 7 \mathrm{H}_{2} \mathrm{O}$ (Merck), $16.67 \mathrm{gL}^{-1} \mathrm{ZnCl}_{2} 2 \mathrm{H}_{2} \mathrm{O}$ (Riedel-deHaën) and $0.17 \mathrm{gL}^{-1} \mathrm{Na}_{2} \mathrm{MoO}_{4} 2 \mathrm{H}_{2} \mathrm{O}$. The batch medium was supplemented with $2 \mathrm{~mL}$ of $0.2 \mathrm{~g} \mathrm{~L}^{-1}$ biotin stock solution per liter medium. The feed medium consisted of $600 \mathrm{~g} \mathrm{~L}^{-1}$ glucose monohydrate, $2 \mathrm{~g} \mathrm{~L}^{-1}\left(\mathrm{NH}_{4}\right)_{2} \mathrm{PO}_{4}$ and $1 \mathrm{~g} \mathrm{~L} \mathrm{~L}^{-1}$ Glanapon DG160 and was supplemented with $2 \mathrm{~mL}$ of biotin stock solution per liter medium.

High cell-density fermentations were carried out in $1 \mathrm{~L}$ bioreactors (DASGIP). A starting volume of $500 \mathrm{~mL}$ batch medium was inoculated to an $\mathrm{OD}_{600}$ of 0.3 . The $\mathrm{pH}$ was measured using a glass electrode (Mettler Toledo) and maintained at $5.0 \pm 0.1$ by automatic addition of $25 \%$ ammonium hydroxide (AppliChem). Dissolved oxygen (DO) was monitored using an optical, dissolved oxygen electrode (Hamilton) and maintained at $20 \%$ of saturation during the batch phase by a DO cascade of agitation and aeration. Hypoxic conditions were applied during the feed phase. Maximum agitation was $1200 \mathrm{rpm}$ (corresponding to a maximum tip speed of $2.89 \mathrm{~m} \mathrm{~s}^{-1}$ ); maximum aeration was set to $1.3 \mathrm{vvm}$. Temperature was maintained at $25^{\circ} \mathrm{C}$.

\section{SDS-PAGE and western blot}

$10 \mu \mathrm{L}$ of culture supernatant (containing secreted carboxylesterase enzyme) were run on a reducing sodium dodecyl sulfate (SDS) NuPAGE ${ }^{\oplus} 12 \%$ Bis-Tris polyacrylamide gel (Life technologies ${ }^{\mathrm{Tm}}$ ) with $\mathrm{NuPAGE}^{\oplus}$ morpholinepropanesulfonic acid (MOPS) buffer at $180 \mathrm{~V}$ for $60 \mathrm{~min}$. Protein bands were visualized using Coomassie staining solution. For Western blotting, SDS-PAGE separated proteins were transferred to a nitrocellulose membrane using the XCell II $^{\mathrm{si}}$ Blot Module for wet (tank) transfer (Life technologies ${ }^{\mathrm{TM}}$ ) according to the manufacturer's instructions. Carboxylesterase was detected using anti-carboxylesterase antiserum as described by Heinl et al. [48].

\section{Gene copy number determination using real time PCR}

Copy numbers were determined by Real time (RT)-PCR as described by Abad et al. [54]. The ABI PRISM 7300 Real Time PCR System and Power SYBR ${ }^{\circ}$ Green PCR Master Mix were used (Life technologies ${ }^{\mathrm{Ta}}$ ). Normalization of the data was achieved using the $P$. pastoris ARG4 gene as reference. The number of copies per $\mu \mathrm{L}$ was calculated using Avogadro's number. Following primers were used for amplification: ARG4-RTfw (TCCTCCGGTGGCAG TTCTT), ARG4-RTrv (TCCATTGACTCCCGTTTGAG), AFT-RTfw (GGGCAATATCCAATAGGGCTAA), AFTRTrv (GGGTGCGCCAAGACTAACA), ZEO-RTfw (CG GCCTGGACGAGCTGTA), ZEO-RTrv (GGCTGCTCG CCGATCTC). Genomic DNA was prepared according to Hoffman and Winston [55].

\section{Fluorescence measurements}

GFP fluorescence levels were determined per $50 \mu \mathrm{L}$ of cell culture. Measurements were performed in microplate using the SynergyMX plate reader (Biotek) applying the following settings: excitation $395 \mathrm{~nm}$ and emission $507 \mathrm{~nm}$.

\section{Carboxylesterase activity assay}

Enzymatic activity was determined photometrically at $405 \mathrm{~nm}$ by hydrolysis of p-Nitrophenyl 2-(trimethylsilyl) ethyl carbonate (pNSi) to p-Nitrophenol + 2-(trimethylsilyl) ethanol + carbon dioxide. The reaction was performed at $37^{\circ} \mathrm{C}$ in microtiter plates and followed over time using a Tecan Sunrise ${ }^{\mathrm{T} M}$ plate reader (XFLUOR4 version: V 4.51). Clarified fermentation supernatants were used undiluted and in several dilutions $\left(10^{-1}-10^{-5}\right)$ using $1 \times$ FCE buffer. 
$10 \times$ FCE buffer consisted of $200 \mathrm{mM}$ Tris-Cl, $\mathrm{pH} 8.0$ and $1 \mathrm{mg} \mathrm{mL}^{-1}$ BSA. $100 \mathrm{mM}$ pNSi stock solution was prepared by dissolving $141.68 \mathrm{mg}$ pNSi in $5 \mathrm{~mL}$ of $96 \%$ ethanol. $1 \mathrm{mM}$ pNSi reaction solution was made by mixing $100 \mathrm{mM}$ pNSi stock solution with $1 \times$ FCE buffer. $20 \mu \mathrm{L}$ of the test samples were provided in a microtiter plate and the reaction was started by addition of $180 \mu \mathrm{L}$ reaction solution. Absorbance was measured every $30 \mathrm{~s}$ for $2 \mathrm{~h}$ and activity was determined according to Lambert-Beer's law.

\section{Iron-dependent growth analysis: spotting assay}

The ferrous iron chelator Bathophenanthrolinedisulfonate disodium salt (BPS; Sigma) reduces the amount of free iron in the medium. YP agar plates containing $80-200 \mu \mathrm{M}$ BPS were prepared by addition of BPS to the melted YP or YPD (YP $+2 \%$ glucose) agar right before pouring the plates. Methanol (1\%) was applied directly in $250 \mu \mathrm{L}$ volumes onto $\mathrm{YP}$ agar plates and spread using a sterile spatula. YNB agar plates containing $200 \mu \mathrm{M}$ BPS were prepared by addition of BPS to the melted YNB agar right before pouring the plates. YNB agar contained $3.4 \mathrm{~g} \mathrm{~L}^{-1}$ Yeast Nitrogen Base (Becton Dickinson, NJ), $10 \mathrm{~g} \mathrm{~L}^{-1}$ ammonium sulfate, $20 \mathrm{~g} \mathrm{~L}^{-1}$ glucose and $100 \mathrm{mM}$ potassium phosphate buffer ( $\mathrm{pH} \mathrm{6.0).}$ Cells from a YPD agar plate were resuspended in $1 \mathrm{~mL}$ sterile $\mathrm{PBS}$, the optical density $\left(\mathrm{OD}_{600}\right)$ was determined and set to $\mathrm{OD}_{600}=0.3$. Five $\mu \mathrm{L}$ of serial $1: 10$ dilutions (in sterile PBS) were applied on each agar plate. The plates were then incubated at $30^{\circ} \mathrm{C}$ for $72 \mathrm{~h}$.

\section{Regulatory sequence analysis tools (RSAT)}

RSAT subcategory pattern matching and string genomescale dna-pattern was used to search for the $S$. cerevisiae Aft1 and Aft2 binding sites within -1000 bp upstream of the $P$. pastoris GS115 coding sequences. Default settings were applied.

\section{AmiGO Go Slimmer}

AmiGO Go Slimmer (version 1.8) was used to map genes into GO slim terms according to their biological process. SGD was used as database filter (Evidence Code: all) and Yeast GO slim as pre-existing GO slim set (GO database release: 27.10.2012 (analysis of P. pastoris Aft1 binding sites) and 15.07.2013 (analysis of microarray data: $\triangle a f t 1$ vs. control). Advanced results option was used to display gene products and counts for each slim term.

\section{Microarray hybridization and data analysis}

For the generation of samples for microarray analysis the $\Delta a f t 1$ strain and the wild type control were cultivated in three biological replicates. Pre-cultures were cultivated as described above. The main cultures, containing $2 \mathrm{~mL} \mathrm{M} 2$ medium, were inoculated to an optical density $\mathrm{OD}_{600}$ of
4.0 and a $12 \mathrm{~mm}$ glucose FeedBead (Kuhner Shaker) was added. The synthetic medium M2 contained per liter: $22.0 \mathrm{~g}$ Citric acid monohydrate, $3.15 \mathrm{~g}\left(\mathrm{NH}_{4}\right)_{2} \mathrm{PO}_{4}, 0.49 \mathrm{~g}$ $\mathrm{MgSO}_{4} * 7 \mathrm{H} 2 \mathrm{O}, 0.80 \mathrm{~g} \mathrm{KCl}, 0.0268 \mathrm{~g} \mathrm{CaCl}_{2}{ }^{*} 2 \mathrm{H}_{2} \mathrm{O}, 1.47 \mathrm{~mL}$ of PTM1 trace metals and $4 \mathrm{mg}$ Biotin; $\mathrm{pH}$ was set to 5 with $\mathrm{KOH}$ (solid). Cultures were shaken at $180 \mathrm{rpm}$ and $25^{\circ} \mathrm{C}$. Slow release of glucose ensured glucose limited growth. Samples were taken after five $\mathrm{h}$ of main culture (estimated specific growth rate: $0.08 \mathrm{~h}^{-1}$ ), fixed in phenol/ ethanol (5\% phenol $(\mathrm{v} / \mathrm{v})$ in pure ethanol, ice-cold), and stored at $-80^{\circ} \mathrm{C}$ until total RNA extraction.

Total RNA extraction was performed using Trizol as described in Graf et al. [42]. cDNA synthesis and labelling as well as the microarray hybridizations (in-house designed $P$. pastoris specific oligonucleotide arrays, AMAD-ID 034821, 8x15K custom arrays, Agilent) were carried out according to the Agilent protocols Quick Amp Labelling Kit (Cat. No. 5190-0444) and Gene Expression Hybridisation Kit (Cat. No. 5188-5242) using a reference design. Therefore, each sample was labelled in a dye-swap manner and hybridized against a reference cDNA, which was generated from a pool of cells grown under different culture conditions. Normalization steps and statistical analysis of microarray data included removal of color bias using locally weighted MA-scatterplot smoothing (LOESS) followed by between array normalization using the "Aquantile" method. For identifying differentially expressed genes and calculating p-values a linear model fit with an eBayes correction was used. P-values were adjusted for multiple testing with the false discovery method (FDR) by Benjamini \& Yekutieli. For identifying differentially expressed genes, a fold change cut-off of at least $1.5>\mathrm{FC}>1 / 1.5$ was applied. All steps were done using the $\mathrm{R}$ software (http://www.rproject.org) and the limma package. The expression changes of some genes selected based on their regulation pattern was confirmed using quantitative real time PCR (Additional file 6).

\section{Additional files}

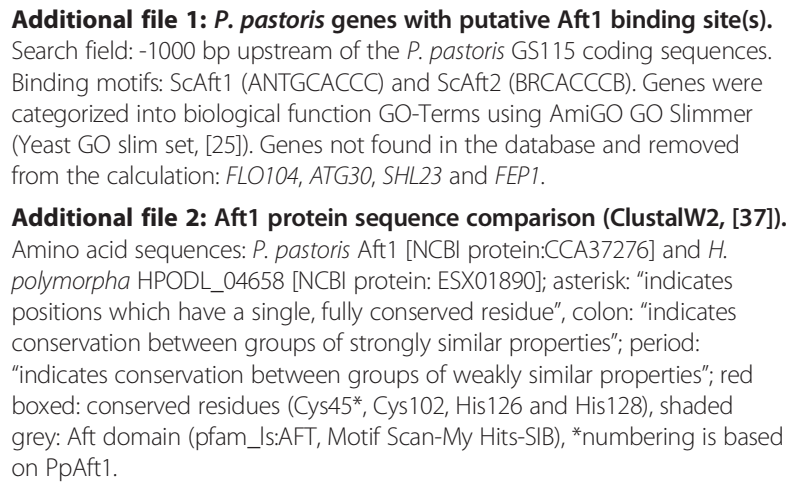

Additional file 1: $P$. pastoris genes with putative Aft1 binding site(s). Search field: -1000 bp upstream of the P. pastoris GS115 coding sequences. Binding motifs: ScAft1 (ANTGCACCC) and SCAft2 (BRCACCCB). Genes were categorized into biological function GO-Terms using AmiGO GO Slimmer (Yeast GO slim set, [25]). Genes not found in the database and removed from the calculation: FLO104, ATG30, SHL23 and FEP1.

Additional file 2: Aft1 protein sequence comparison (ClustalW2, [37]). Amino acid sequences: P. pastoris Aft1 [NCBI protein:CCA37276] and H. polymorpha HPODL_04658 [NCBI protein: ESX01890]; asterisk: "indicates positions which have a single, fully conserved residue", colon: "indicates conservation between groups of strongly similar properties"; period: "indicates conservation between groups of weakly similar properties"; red boxed: conserved residues (Cys45*, Cys102, His126 and His128), shaded grey: Aft domain (pfam_Is:AFT, Motif Scan-My Hits-SIB), * numbering is based on PpAft1.

Additional file 3 List of significantly regulated genes in $\Delta$ aft 1 compared to wild type. GO term enrichment was analysed using 
Amigo GO Slimmer [25]. Significantly regulated GO terms were determined by $\mathrm{GO}$ term Finder. List of homologs of the S. cerevisiae iron regulon which are not regulated in $\Delta$ aft 1 in $P$. pastoris.

Additional file 4: SDS-PAGE of carboxylesterase secreting $P$. pastoris strains. Clones \#8-20: CBS7435 transformed with plasmid pPM2dZ30PGAP-CE; negative control: CBS7435.

Additional file 5: Primers used for the construction of the split marker cassette for AFT1 disruption in P. pastoris.

Additional file 6: Primers used for the verification of gene regulation in $\Delta a f t 1$ and wild type. Comparison of gene regulation patterns from microarrays and $\mathrm{QPCR}$ for genes selected based on their regulatory behaviour.

\section{Competing interests}

The authors declare that they have no competing interests.

\section{Authors' contributions}

$C R, S N, D M, H P$ and BG participated in the design of the study. CR and W carried out the sequence analysis, promoter and overexpression studies. Bioreactor cultivations were performed by DK. MB and BG carried out the DNA microarrays and data analysis. CR and MB drafted the manuscript. DK, $\mathrm{SN}, \mathrm{DM}, \mathrm{HP}$ and BG revised the manuscript. All authors read and approved the final manuscript.

\section{Acknowledgements}

This work has been supported by the Federal Ministry of Science, Research and Economy (BMWFW), the Federal Ministry of Traffic, Innovation and Technology (bmvit), the Styrian Business Promotion Agency SFG, the Standortagentur Tirol and ZIT - Technology Agency of the City of Vienna through the COMET-Funding Program managed by the Austrian Research Promotion Agency FFG. Further support by Biomin Research Center, Boehringer-Ingelheim RCV, Lonza AG, Biocrates Life Sciences AG, VTU Technology $\mathrm{GmbH}$, and Sandoz $\mathrm{GmbH}$ is acknowledged. The carboxylesterase activity assay with pNSi as substrate originated at evocatal $\mathrm{GmbH}$, Monheim am Rhein, Germany. The authors thank Dr. Alexandra B. Graf (University of Applied Sciences - FH Campus Vienna) for the processing of the microarray data, Dr. Minoska Valli (ACIB) for help with P. pastoris gene annotation, and Gabriele Wilt (ACIB) and Elena Pietrich (ACIB) for their excellent technical support.

\section{Author details}

${ }^{1}$ Austrian Centre of Industrial Biotechnology (ACIB GmbH), Petersgasse 14, $8010 \mathrm{Graz}$, Austria. ${ }^{2}$ Austrian Centre of Industrial Biotechnology (ACIB GmbH), Muthgasse 11, 1190 Wien, Austria. ${ }^{3}$ BIOMIN Research Center, Technologiezentrum Tulln, Technopark 1, 3430 Tulln, Austria. ${ }^{4}$ Department of Biotechnology, BOKU University of Natural Resources and Life Sciences Vienna, Muthgasse 18, 1190 Vienna, Austria. Institute of Molecular Biotechnology, Graz University of Technology, Petersgasse 14, 8010 Graz, Austria.

Received: 8 May 2014 Accepted: 10 August 2014

Published: 3 September 2014

\section{References}

1. Gasser B, Prielhofer R, Marx H, Maurer M, Nocon J, Steiger M, Puxbaum V, Sauer M, Mattanovich D: Pichia pastoris: protein production host and model organism for biomedical research. Future Microbiol 2013, 8:191-208.

2. Damasceno LM, Anderson KA, Ritter G, Cregg JM, Old L, Batt CA: Cooverexpression of chaperones for enhanced secretion of a single-chain antibody fragment in Pichia pastoris. App/ Microbiol Biotechnol 2007, 74:381-389.

3. Gasser B, Sauer M, Maurer M, Stadlmayr G, Mattanovich D: Transcriptomics-based identification of novel factors enhancing heterologous protein secretion in yeasts. Appl Environ Microbiol 2007, 73:6499-6507.

4. Guerfal M, Ryckaert S, Jacobs PP, Ameloot P, Van Craenenbroeck K, Derycke R, Callewaert N: The HAC1 gene from Pichia pastoris: characterization and effect of its overexpression on the production of secreted, surface displayed and membrane proteins. Microb Cell Fact 2010, 9:49.
5. Gasser B, Maurer M, Gach J, Kunert R, Mattanovich D: Engineering of Pichia pastoris for improved production of antibody fragments. Biotechnol Bioeng 2006, 94:353-361.

6. Stadlmayr G, Benakovitsch K, Gasser B, Mattanovich D, Sauer M: Genome-scale analysis of library sorting (GALibSo): isolation of secretion enhancing factors for recombinant protein production in Pichia pastoris. Biotechnol Bioeng 2010, 105:543-555.

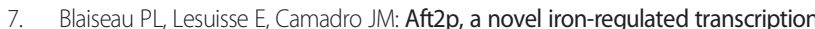
activator that modulates, with Aft1p, intracellular iron use and resistance to oxidative stress in yeast. J Bio/ Chem 2001, 276:34221-34226.

8. Rutherford JC, Jaron S, Winge DR: Aft1p and Aft2p mediate iron-responsive gene expression in yeast through related promoter elements. J Biol Chem 2003, 278:27636-27643

9. Rutherford JC, Ojeda L, Balk J, Mühlenhoff U, Lill R, Winge DR: Activation of the iron regulon by the yeast Aft1/Aft2 transcription factors depends on mitochondrial but not cytosolic iron-sulfur protein biogenesis. J Biol Chem 2005, 280:10135-10140.

10. Yamaguchi-Iwai Y, Dancis A, Klausner RD: AFT1: a mediator of iron regulated transcriptional control in Saccharomyces cerevisiae. EMBO 1995, 14:1231-1239.

11. Yamaguchi-Iwai $Y$, Stearman R, Dancis A, Klausner RD: Iron-regulated DNA binding by the AFT1 protein controls the iron regulon in yeast. EMBO J 1996, 15:3377-3384.

12. Ueta R, Fujiwara N, Iwai K, Yamaguchi-Iwai Y: Iron-induced dissociation of the Aft1p transcriptional regulator from target gene promoters is an initial event in iron-dependent gene suppression. Mol Cell Biol 2012, 32:4998-5008

13. Ueta R, Fujiwara N, Iwai K, Yamaguchi-iwai Y: Mechanism underlying the iron-dependent nuclear export of the iron-responsive transcription factor Aft1p in Saccharomyces cerevisiae. Mol Cell Biol 2007, 18:2980-2990.

14. Conde e Silva N, Gonçalves IR, Lemaire M, Lesuisse E, Camadro JM, Blaiseau PL: $\mathrm{KIAft}$, the Kluyveromyces lactis ortholog of Aft1 and Aft2, mediates activation of iron-responsive transcription through the PuCACCC Aft-type sequence. Genetics 2009, 183:93-106.

15. Haas H, Eisendle M, Turgeon BG: Siderophores in fungal physiology and virulence. Annu Rev Phytopathol 2008, 46:149-187.

16. Miele R, Barra D, di Patti MC B: A GATA-type transcription factor regulates expression of the high-affinity iron uptake system in the methylotrophic yeast Pichia pastoris. Arch Biochem Biophys 2007, 465:172-179.

17. Lan C-Y, Rodarte G, Murillo LA, Jones T, Davis RW, Dungan J, Newport G, Agabian N: Regulatory networks affected by iron availability in Candida albicans. Mol Microbiol 2004, 53:1451-1469.

18. Cartharius K, Frech K, Grote K, Klocke B, Haltmeier M, Klingenhoff A, Frisch M, Bayerlein M, Werner T: MatInspector and beyond: promoter analysis based on transcription factor binding sites. Bioinformatics 2005, 21:2933-2942

19. Gasser B, Saloheimo M, Rinas U, Dragosits M, Rodríguez-Carmona E, Baumann K, Giuliani M, Parrilli E, Branduardi P, Lang C, Porro D, Ferrer P, Tutino ML, Mattanovich D, Villaverde A: Protein folding and conformational stress in microbial cells producing recombinant proteins: a host comparative overview. Microb Cell Fact 2008, 7:11.

20. Idiris A, Tohda $H$, Kumagai $H$, Takegawa K: Engineering of protein secretion in yeast: strategies and impact on protein production. Appl Microbiol Biotechnol 2010, 86:403-417.

21. Vogl T, Thallinger GG, Zellnig G, Drew D, Cregg JM, Glieder A, Freigassner M: Towards improved membrane protein production in Pichia pastoris: general and specific transcriptional response to membrane protein overexpression. N Biotechnol 2014, S1871-6784(14)00022-3. doi: 10.1016/j. nbt.2014.02.009. [Epub ahead of print]

22. Daum G, Tuller G, Nemec T, Hrastnik C, Balliano G, Cattel L, Milla P, Rocco F, Conzelmann A, Vionnet C, Kelly DE, Kelly S, Schweizer E, Schüller HJ, Hojad $U$, Greiner E, Finger K: Systematic analysis of yeast strains with possible defects in lipid metabolism. Yeast 1999, 15:601-614.

23. Thomas-Chollier M, Defrance M, Medina-Rivera A, Sand O, Herrmann C, Thieffry D, van Helden J: RSAT 2011: regulatory sequence analysis tools. Nucleic Acids Res 2011, 39(Web Server issue):W86-W91.

24. Mattanovich D, Callewaert N, Rouzé P, Lin Y-C, Graf A, Redl A, Tiels P, Gasser B, De Schutter K: Open access to sequence: browsing the Pichia pastoris genome. Microb Cell Fact 2009, 8:53.

25. Ashburner M, Ball CA, Blake JA, Botstein D, Butler H, Cherry JM, Davis AP, Dolinski K, Dwight SS, Eppig JT, Harris MA, Hill DP, Issel-Tarver L, Kasarskis A, 
Lewis S, Matese JC, Richardson JE, Ringwald M, Rubin GM, Sherlock G: Gene ontology: tool for the unification of biology. the Gene Ontology Consortium. Nat Genet 2000, 25:25-29.

26. Li L, Chen OS, McVey Ward D, Kaplan J: CCC1 is a transporter that mediates vacuolar iron storage in yeast. J Biol Chem 2001, 276:29515-29519.

27. Greene JR, Brown NH, DiDomenico BJ, Kaplan J, Eide DJ: The GEF1 gene of Saccharomyces cerevisiae encodes an integral membrane protein; mutations in which have effects on respiration and iron-limited growth. Mol Gen Genet 1993, 241:542-553.

28. Kim D, Yukl ET, Moënne-Loccoz P, Montellano PR: Fungal heme oxygenases: functional expression and characterization of $\mathrm{Hmx} 1$ from Saccharomyces cerevisiae and $\mathrm{CaHm} \times 1$ from Candida albicans. Biochemistry 2006, 45:14772-14780.

29. Collinson EJ, Wimmer-Kleikamp S, Gerega SK, Yang YH, Parish CR, Dawes IW, Stocker R: The yeast homolog of heme oxygenase-1 affords cellular antioxidant protection via the transcriptional regulation of known antioxidant genes. J Biol Chem 2011, 286:2205-2214.

30. Schilke B, Voisine C, Beinert $\mathrm{H}$, Craig E: Evidence for a conserved system for iron metabolism in the mitochondria of Saccharomyces cerevisiae. Proc Natl Acad Sci U S A 1999, 96:10206-10211.

31. Lee MCS, Miller EA: Molecular mechanisms of COPII vesicle formation. Semin Cell Dev Biol 2007, 18:424-434.

32. Römisch K: Surfing the Sec61 channel: bidirectional protein translocation across the ER membrane. J Cell Sci 1999, 112(Pt 2):4185-4191.

33. McNew JA, Coe JG, Søgaard M, Zemelman BV, Wimmer C, Hong W, Söllner TH: Gos1p, a Saccharomyces cerevisiae SNARE protein involved in Golgi transport. FEBS Lett 1998, 435:89-95.

34. Kuge $\mathrm{S}$, Jones N: YAP1 dependent activation of TRX2 is essential for the response of Saccharomyces cerevisiae to oxidative stress by hydroperoxides. EMBO J 1994, 13:655-664.

35. Vervecken W, Kaigorodov V, Callewaert N, Geysens S, De Vusser K, Contreras R: In vivo synthesis of mammalian-like, hybrid-type $\mathrm{N}$-glycans in pichia pastoris. 2004, 70:2639-2646.

36. Elbert M, Rossi G, Brennwald P: The yeast par-1 homologs kin1 and kin2 show genetic and physical interactions with components of the exocytic machinery. Mol Biol Cell 2005, 16:532-549.

37. Larkin MA, Blackshields G, Brown NP, Chenna R, McGettigan PA, McWilliam H, Valentin F, Wallace IM, Wilm A, Lopez R, Thompson JD, Gibson TJ, Higgins DG: Clustal W and Clustal X version 2.0. Bioinformatics 2007, 23:2947-2948

38. Rutherford JC, Jaron S, Ray E, Brown PO, Winge DR: A second iron-regulatory system in yeast independent of Aft1p. Proc Natl Acad Sci U S A 2001, 98:14322-14327.

39. Babu MM, lyer LM, Balaji S, Aravind L: The natural history of the WRKY-GCM1 zinc fingers and the relationship between transcription factors and transposons. Nucleic Acids Res 2006, 34:6505-6520.

40. Alberts B, Bray D, Lewis J, Raff M, Roberts K, Watson JD: Molecular Biology of the Cell, 3rd Addition. New York: Garland Science; 1994.

41. Heiss S, Maurer M, Hahn R, Mattanovich D, Gasser B: Identification and deletion of the major secreted protein of Pichia pastoris. App/ Microbiol Biotechnol 2013, 97:1241-1249.

42. Graf A, Gasser B, Dragosits M, Sauer M, Leparc GG, Tüchler T, Kreil DP, Mattanovich D: Novel insights into the unfolded protein response using Pichia pastoris specific DNA microarrays. BMC Genomics 2008, 9:390.

43. Baumann $K$, Carnicer M, Dragosits M, Graf AB, Stadlmann J, Jouhten $P$, Maaheimo H, Gasser B, Albiol J, Mattanovich D, Ferrer P: A multi-level study of recombinant Pichia pastoris in different oxygen conditions. BMC Syst Biol 2010, 4:141

44. Nocon J, Steiger MG, Pfeffer M, Sohn SB, Kim TY, Maurer M, Rußmayer H, Pflügl S, Ask M, Haberhauer-Troyer C, Ortmayr K, Hann S, Koellensperger G, Gasser B, Lee SY, Mattanovich D: Model based engineering of Pichia pastoris central metabolism enhances recombinant protein production. Metab Eng 2014, 24:129-138. doi:10.1016/j.ymben.2014.05.011.

45. Crameri A, Whitehorn EA, Tate E, Stemmer WP: Improved green fluorescent protein by molecular evolution using DNA shuffling. Nat Biotechnol 1996, 14:315-319.

46. Hartner FS, Ruth C, Langenegger D, Johnson SN, Hyka P, Lin-Cereghino GP, Lin-Cereghino J, Kovar K, Cregg JM, Glieder A: Promoter library designed for fine-tuned gene expression in Pichia pastoris. Nucleic Acids Res 2008, 36:e76.
47. Hartinger D, Moll W-D: Fumonisin elimination and prospects for detoxification by enzymatic transformation. World Mycotoxin J 2011, 4:271-283.

48. Heinl S, Hartinger D, Thamhesl M, Vekiru E, Krska R, Schatzmayr G, Moll W-D, Grabherr R: Degradation of fumonisin B1 by the consecutive action of two bacterial enzymes. J Biotechnol 2010, 145:120-129.

49. Baumann K, Maurer M, Dragosits M, Cos O, Ferrer P, Mattanovich D: Hypoxic fed-batch cultivation ofPichia pastoris increases specific and volumetric productivity of recombinant proteins. Biotechnol Bioeng 2008 100:177-183.

50. Küberl A, Schneider J, Thallinger GG, Anderl I, Wibberg D, Hajek T, Jaenicke S, Brinkrolf K, Goesmann A, Szczepanowski R, Pühler A, Schwab H, Glieder A, Pichler H: High-quality genome sequence of Pichia pastoris CBS7435. J Biotechnol 2011, 154:312-320.

51. Näätsaari L, Mistlberger B, Ruth C, Hajek T, Hartner FS, Glieder A: Deletion of the Pichia pastoris KU70 homologue facilitates platform strain generation for gene expression and synthetic biology. PLoS One 2012, 7:e39720.

52. Weis R, Luiten R, Skranc W, Schwab H, Wubbolts M, Glieder A: Reliable high-throughput screening with Pichia pastoris by limiting yeast cell death phenomena. FEMS Yeast Res 2004, 5:179-189.

53. Zhao W, Wang J, Deng R, Wang X: Scale-up fermentation of recombinant Candida rugosa lipase expressed in Pichia pastoris using the GAP promoter. J Ind Microbiol Biotechnol 2008, 35:189-195.

54. Abad S, Kitz K, Hörmann A, Schreiner U, Hartner FS, Glieder A: Real-time PCR-based determination of gene copy numbers in Pichia pastoris. Biotechnol J 2010, 5:413-420.

55. Hoffman CS, Winston F: A ten-minute DNA preparation from yeast efficiently releases autonomous plasmids for transformation of Escherichia coli. Gene 1987, 57:267-272.

doi:10.1186/s12934-014-0120-5

Cite this article as: Ruth et al:: Pichia pastoris Aft1 - a novel transcription factor, enhancing recombinant protein secretion. Microbial Cell Factories 2014 13:120.

\section{Submit your next manuscript to BioMed Central and take full advantage of:}

- Convenient online submission

- Thorough peer review

- No space constraints or color figure charges

- Immediate publication on acceptance

- Inclusion in PubMed, CAS, Scopus and Google Scholar

- Research which is freely available for redistribution

Submit your manuscript at www.biomedcentral.com/submit
C Biomed Central 